\title{
STUDY OF CLINICAL PROFILE OF BREAST CANCER PATIENTS AT A TERTIARY CARE HOSPITAL, MIMS, MANDYA
}

\author{
Narashimhaswamy $P^{1}$, Venkatesh $N^{2}$, Lingaraju N3, Murali Mohan $R^{4}$ \\ 1 Professor and HOD, Department of Surgery, Mandya Institute of Medical Sciences, Mandya. \\ 2Surgical Oncologist, Mandya Institute of Medical Sciences, Mandya. \\ ${ }_{3}^{3}$ Associate Professor, Department of Surgery, Mandya Institute of Medical Sciences, Mandya. \\ ${ }^{4}$ Associate Professor, Department of surgery, Mandya Institute of Medical Sciences, Mandya.
}

\section{ABSTRACT}

Breast cancer contributes for $5-8 \%$ of all cancer in India, and there is a rising trend in its incidence as the most common type of cancer in urban Indian women and the second most common type of cancer in rural women. The probability of developing breast cancer during lifetime in Indian women is 1 in 22 as compared to 1 in 8 women in the United States and other developed countries. There are considerable variations in risk factors, presenting stage and prognostic factors such as receptor status.

\section{AIM}

To evaluate the clinical profile of patients presenting with breast cancer to a tertiary care hospital, MIMS, Mandya.

\section{MATERIALS AND METHODS}

It was an observational, cross-sectional study done in the Department of Surgery/Onco Surgery, MIMS, Mandya, a tertiary care centre from Oct. 2015 to March 2016. Patients diagnosed as carcinoma breast were registered; detailed history, clinical examination and necessary investigations performed.

\section{RESULTS AND CONCLUSIONS}

The incidence was high (80\%) among women age ranging from 30 to 60 . The majority of women presented with lump (90\%) and others with nipple retraction (14\%), ulceration (20\%), discharge (10\%), and symptoms of metastasis (12\%). Upper outer quadrant was the common site of tumour in more than $50 \%$ of patients, IDC was the common histology, most of patients presented in stage $2 / 3$.

\section{KEYWORDS}

Palpable Breast Lump, Carcinoma Breast, Triple Assessment.

HOW TO CITE THIS ARTICLE: Narashimhaswamy P, Venkatesh N, Lingaraju N, et al. Study of clinical profile of breast cancer patients at a tertiary care hospital, MIMS, Mandya. J. Evolution Med. Dent. Sci. 2016;5(35):1976-1978, DOI: 10.14260/jemds/2016/467

\section{INTRODUCTION}

Breast cancer is one of the common and leading causes of cancer related death in females and account for $29 \%$ of all cancers diagnosed each year worldwide. ${ }^{1}$ It is the most common type of cancer in urban Indian women and the second most common type of cancer in rural women. ${ }^{2}$ The probability of developing breast cancer during lifetime in Indian women is 1 in 22 as compared to 1 in 8 women in the United States and other developed countries. ${ }^{3}$

Breast cancer is a disease of the old age with the peak incidence in the fifth and sixth decades, but in India the disease is seen a decade earlier, probably because of shorter life expectancy in Indian women (about 65.3 years as per Indian data in 2005) as compared to counterparts in USA. Studies show that the breast cancer in younger women is unique and needs a different treatment strategy than what might be used for older women with breast cancer.4-6

Genetic differences, the stage of disease at the time of diagnosis, availability of proper and appropriate care are some of the factors which explain the differences in incidence, clinical profile and outcome of the patients. ${ }^{7}$

Financial or Other, Competing Interest: None.

Submission 14-03-2016, Peer Review 09-04-2016,

Acceptance 15-04-2016, Published 30-04-2016.

Corresponding Author

Dr. Lingaraju $N$,

House No. 704B, Doctors Quarters,

Mandya Institute of Medical Sciences,

Mandya-571401.

E-mail: lingu1983@yahoo.com

DOI: $10.14260 /$ jemds/2016/467
Present study describes the clinical profile of Breast cancer patients visiting a tertiary care hospital, Mandya Institute of Medical Sciences, Mandya.

\section{METHODS}

It was an observational, cross-sectional study. Total 50 patients of newly diagnosed cases of breast cancer attending the General Surgery/Oncosurgery Outpatient Department were enrolled in the study. Patients operated at other centres, patients with recurrent disease were not included in the study. Detailed history, clinical examination and necessary investigations performed. Patients were staged as per TNM staging.

\section{RESULTS AND ANALYSIS}

\begin{tabular}{|c|c|c|}
\hline Age Group & No. of Patients & Percentage \\
\hline$<30$ Years & 03 & $06 \%$ \\
\hline $30-60$ & 40 & $80 \%$ \\
\hline$>60$ & 07 & $14 \%$ \\
\hline \multicolumn{2}{|c|}{ case of male breast cancer in a 55-year-old man } \\
\hline \multicolumn{2}{|c|}{ Table 1: Distribution Based on Age Group } \\
\hline
\end{tabular}

\begin{tabular}{|c|c|c|}
\hline Clinical Parameter & No. of Patients & Percentage \\
\hline Side Involved & & \\
\hline Right & 23 & $46 \%$ \\
\hline Left & 27 & $54 \%$ \\
\hline Duration of Symptoms & & \\
\hline$<2$ months & 10 & $20 \%$ \\
\hline $2-6$ months & 27 & $54 \%$ \\
\hline$>6$ months & 13 & $26 \%$ \\
\hline Size of Lump & \multicolumn{2}{|}{} \\
\hline \multicolumn{2}{|l}{} \\
\hline
\end{tabular}




\begin{tabular}{|c|c|c|}
\hline$<2 \mathrm{cms}$ & 03 & $06 \%$ \\
\hline $2-5 \mathrm{cms}$ & 11 & $22 \%$ \\
\hline$>5 \mathrm{cms}$ & 36 & $72 \%$ \\
\hline Nipple Retraction & & \\
\hline Present & 07 & $14 \%$ \\
\hline Absent & 43 & $96 \%$ \\
\hline Nipple Discharge & 05 & $10 \%$ \\
\hline Present & 45 & $90 \%$ \\
\hline Absent & 10 & $20 \%$ \\
\hline Skin Changes & 40 & $80 \%$ \\
\hline Present & Table 2 \\
\hline Absent & \\
\hline \multicolumn{2}{|c|}{} \\
\hline
\end{tabular}

\begin{tabular}{|c|c|c|}
\hline Parameter & No. of Patients & Percentage \\
\hline Parity & 05 & $10 \%$ \\
\hline Nulliparous & 45 & $90 \%$ \\
\hline Multiparous & & \\
\hline $\begin{array}{c}\text { Family History } \\
\text { of CA Breast }\end{array}$ & 2 & $4 \%$ \\
\hline Present & 48 & $96 \%$ \\
\hline Absent & Table 3 \\
\hline
\end{tabular}

\begin{tabular}{|c|c|c|}
\hline Location of Tumour & No. of Patients & Percentage \\
\hline Upper outer quadrant & 26 & $52 \%$ \\
\hline Upper inner quadrant & 06 & $12 \%$ \\
\hline Lower outer quadrant & 01 & $02 \%$ \\
\hline Lower inner quadrant & 04 & $08 \%$ \\
\hline Central quadrant & 13 & $26 \%$ \\
\hline \multicolumn{3}{|c|}{ Table 4 } \\
\hline
\end{tabular}

\begin{tabular}{|c|c|c|}
\hline Stage of Disease & No. of Patients & Percentage \\
\hline Early breast cancer & 07 & $14 \%$ \\
\hline Locally advanced BC & 37 & $74 \%$ \\
\hline Metastatic breast cancer & 06 & $12 \%$ \\
\hline \multicolumn{2}{|c|}{ Table 5 } \\
\hline
\end{tabular}

\begin{tabular}{|c|c|c|}
\hline $\begin{array}{c}\text { Histological } \\
\text { Type }\end{array}$ & No. of Patients & Percentage \\
\hline Carcinoma in-situ & NIL & 0 \\
\hline $\begin{array}{c}\text { Infiltrating ductal } \\
\text { carcinoma }\end{array}$ & 48 & $96 \%$ \\
\hline $\begin{array}{c}\text { Infiltrating lobular } \\
\text { carcinoma }\end{array}$ & NIL & 0 \\
\hline $\begin{array}{c}\text { Malignant phyllodes } \\
\text { tumour }\end{array}$ & 01 & $2 \%$ \\
\hline Paget's disease & 01 & $2 \%$ \\
\hline \multicolumn{2}{|c|}{ Table 6 } \\
\hline
\end{tabular}

\section{DISCUSSION}

Worldwide breast cancer is the most frequent cancer in women and represents the second leading cause of cancer death among women (After lung cancer). 8,9 Presently, 75,000 new cases occur in Indian women every year. 10 This figure must be viewed against the backdrop that the National Cancer Registry and the Hospital-Based Tumour Registries hardly sample $3 \%$ of the total population. Locally Advanced Breast Cancer (LABC) constitutes more than 50 to $70 \%$ of the patients presenting for treatment.

Clinically, the relation between tumour size and lymph node involvement is well known. ${ }^{11}$ and it is the only most powerful indicator of poor prognosis in breast cancer.12,13 Breast cancer in younger women that are diagnosed with a palpable mass have larger tumour sizes, more lymph node metastasis and are more invasive cancers than those in older women. Metastasis to the lymph nodes is an important prognostic factor, which indicate advanced disease status with the probability that cancer cells have spread to distant sites. At diagnosis, $30 \%$ to $50 \%$ of all breast cancers have spread to the sentinel lymph node. ${ }^{14-16}$

The data regarding the location of lump in present study is comparable with that reported by RK Gange et al ${ }^{17}$ in which case location of the lump was in upper outer quadrant in $48 \%$ cases, lower outer quadrant in $10 \%$ cases, lower inner quadrant in $12 \%$ cases and central quadrant in $12 \%$ cases.

In our study, the most frequent age group to have diagnosed breast cancer was between 30 yrs. to $60 \mathrm{yrs}$. of age. Also in this study, $60 \%$ of cases were premenopausal and remaining 40 percent were postmenopausal.

In this study, majority of cases were in stage III and stage II; infiltrating ductal carcinoma (98\%) was the most common histopathological type in the present study. Similar observations have been reported by Haque $\mathrm{R}$ et al ${ }^{18}$ with $75 \%$ cases being infiltrating ductal carcinoma in their study and Gupta JC et al ${ }^{19}$ with $91.1 \%$ cases of infiltrating ductal carcinoma in their study.

One case of male breast carcinoma were reported in the present study. However, study has its limitations which include an observational study design, small sample size, nonavailability of ER/PR receptor status. However, it gives valuable information regarding the clinical profile and outcome of breast cancer patients in our setup.

\section{CONCLUSION}

The incidence was high (80\%) among women age ranging from 30 to 60 . The majority of women presented with lump $(90 \%)$ and others with nipple retraction (14\%), ulceration (20\%), discharge (10\%), and symptoms of metastasis (12\%). Upper outer quadrant was the common site of tumour in more than $50 \%$ of patients. Infiltrating ductal carcinoma was the common histology, most of the patients presented in stage II and III.

This study highlights the need to support health education regarding the warning signals of breast cancer and its early screening, so that more patients can be diagnosed at an early stage and effective treatment can be given to these women and their lives can be saved. Facility for estimation of ER/PR receptor status should be made available, so that outcome can be improved. More, larger in-depth studies are needed to investigate the aetiology of breast cancer in younger patients.

\section{REFERENCES}

1. Box BA, Russell CA. Breast cancer. In: Dennis A Casciato, editor. Manual of clinical oncology. Philadelphia: lippincot williams and wilkins 2005; $5^{\text {th }}$ ed:250-3.

2. Agarwal G, Ramakant P. Breast cancer care in India: the current scenario and the challenges for the future. Breast Care (Basel) 2008;3(1):21-7.

3. Kulkarni SS, Kulkarni BB, Vandana T, et al. Expression profiling of brca1 gene in familial breast cancer in India. Afr J Biotechnol 2012;11(37):9123-6.

4. Kollias J, Elston CW, Ellis IO, et al. Early-onset breast cancer- histopathological and prognostic considerations. Br J Cancer 1997;75(9):1318-23. 
5. Shannon C, Smith IE. Breast cancer in adolescents and young women. Eur J Cancer 2003;39(18):2632-42.

6. Anders CK, Hsu DS, Broadwater G, et al. Young age at diagnosis correlates with worse prognosis and defines a subset of breast cancers with shared patterns of gene expression. J Clin Oncol 2008;26(20):3324-30.

7. Hortobagyi GN, de la Garza Salazar J, Pritchard K, et al. The global breast cancer burden: variations in epidemiology and survival. Clin Breast Cancer 2005;6(5):391-401.

8. Dumitrescu RG, Cotarla I. Understanding breast cancer risk-where do we stand in 2005. J Cell Mol Med 2005;9(1):208-21.

9. Chandra AB. Problems and prospects of cancer of the breast in India. J Indian Med Assoc 1979;72(2):43-5.

10. Chopra R. The Indian scene. Journal of Clinical Oncology 2001;19(18):S106-11.

11. Carter CL, Allen C, Henson DE. Relation of tumour size, lymph node status, and survival in 24,740 breast cancer cases. Cancer 1989;63(1):181-7.

12. McGuire WL. Prognostic factors for recurrence and survival in human breast cancer. Breast Cancer Res Treat 1987;10(1):5-9.
13. Foster RS Jr. The biologic and clinical significance of lymphatic metastases in breast cancer. Surg Oncol Clin N Am 1996;5(1):79-104.

14. Vinh-Hung V, Verschraegen C, Promish DI, et al. Ratios of involved nodes in early breast cancer. Breast Cancer Res 2004;6:680-8.

15. Veronesi U, Paganelli G, Viale G, et al. Sentinel lymph node biopsy and axillary dissection in breast cancer: results in a large series. J Natl Cancer Inst 1999;91(4):368-73.

16. Jatoi I, Hilsenbeck SG, Clark GM, et al. Significance of axillary lymph node metastasis in primary breast cancer. J Clin Oncol 1999;17(8):2334-40

17. Gang RK, Bothra VC, Pande SK. Cancer of the breast, a five year review at the mahatma gandhi hospital, jabalpur. Ind J Surg 1982;44:347-50.

18. Haque R, Tyagi SP, Khan MH, et al. Breast lesion: a clinicopathological study of 200 cases of breast lump. Ind J Surg 1980;42:419-25.

19. Gupta JC, Munjal JS, Raman A, et al. Breast lumps in Jabalpur area. Ind J Surg 1983;45:268-73. 